\title{
Analisis Sentimen Terhadap Produk The Body Shop Tea Tree Oil
}

\author{
Abyan Ghiffarie ${ }^{1}$, Ken Dheanis Adhine Salsabila², Rayesha Putra Baistama ${ }^{3}$, \\ Muhammad Iqbal Variadi ${ }^{4}$, Mochamad Daffa Rhajendra ${ }^{5}$ \\ ${ }^{12345}$ S1 Manajemen Bisnis Telekomunikasi dan Informatika, Universitas Telkom \\ e-mail : ${ }^{1}$ ghiffarie17@gmail.com, ${ }^{2}$ kdheanis@gmail.com, ${ }^{3}$ rayeshaputra@gmail.com, \\ 4iqbalvariadi07@gmail.com, ${ }^{5}$ drhajendra@gmail.com
}

\begin{abstract}
ABSTRAK-Tea Tree Oil berasal dari tanaman Melaleuca Alternifolia. Ini sudah digunakan untuk pengobatan dan sudah diidentifikasi sebagai antibiotik oleh New South Wales Chief Chemist pada tahun 1920. The Body Shop merupakan perusahaan kosmetika asal Brazil yang melakukan penetrasi ke pasar Indonesia pada tahun 1990. Tea Tree Oil menjadi produk yang best-seller dan sangat direkomendasikan oleh The Body Shop sendiri. Dalam situs femaledaily.com, produk ini mendapat penghargaan sebagai "Best of Beauty Skin Care" selama 5 tahun berturutturut sejak tahun 2014 hingga 2018. Selain itu, produk ini juga memiliki 3163 ulasan dengan 64\% dari keseluruhan ulasan merekomendasikan produk ini. Dengan menggunakan machine learning dan menerapkan metode Nä̈ve Bayes Classifier, maka dapat dilakukan analisis sentimen terhadap produk The Body Shop Tea Tree Oil berdasarkan ulasan pengguna yang terdapat pada situs femaledaily.com. Data sampel yang digunakan sebanyak 2820 data dengan proporsi $70 \%$ sebagai data training dan $30 \%$ sebagai data testing. Output dari analisis ini berupa jumlah komentar pengguna, topic modelling, dan word cloud dengan sentiment positif dan negatif dan dengan tingkat akurasi model sentiment analysis Tea Tree Oil pada femaledaily sebesar $61.51 \%$.
\end{abstract}

\section{Kata Kunci : Tea Tree Oil, Analisis Sentimen, Perawatan Kulit}

\begin{abstract}
Tea Tree Oil is derived from the Melaleuca Alternifolia plant. It has been used for treatment and was identified as an antibiotic by New South Wales Chief Chemist in 1920. The Body Shop is a cosmetics company from Brazil that penetrated the Indonesian market in 1990. Tea Tree Oil is a best-seller and highly recommended product by The Body Shop itself. On the website femaledaily.com, this product received an award as "Best of Beauty Skin Care" for 5 consecutive years from 2014 to 2018. In addition, this product also has 3163 reviews with 64\% of all reviews recommending this product. By using machine learning and applying the Nä̈ve Bayes Classifier method, sentiment analysis can be carried out on The Body Shop Tea Tree Oil products based on user reviews found on the website femaledaily.com. The sample data used were 2820 data with the proportion of $70 \%$ as training data and $30 \%$ as testing data. The output of this analysis is the number of user comments, topic modeling, and word cloud with positive and negative sentiments and with the accuracy level of Tea Tree Oil sentiment analysis models on femaledaily at $61.51 \%$.
\end{abstract}

\section{Index Terms : Tea Tree Oil, Sentiment Analysis, Skin Care}




\section{PENDAHULUAN}

Penggunaan skin care oleh kaum wanita menjadi suatu kewajiban di era modern zaman sekarang. Bahkan produk-produk perawatan kulit digunakan untuk kebutuhan kecantikan wanita maupun pria dari kalangan muda sampai tua. Bermacam macam produk mempunyai kegunaannya masing masing, mulai dari untuk mengurangi jerawat, mempercerah kulit, dan menjaga kesehatan kulit.

Salah satu produsen kosmetik di Indonesia adalah The Body Shop. Perusahaan kosmetika asal Brazil ini melakukan penetrasi ke pasar Indonesia pada tahun 1990, hingga tahun 2017 The Body Shop Indonesia (TBSI) memiliki 153 toko yang secara eksklusif berlokasi di mall pada 39 kota di Indonesia.

Salah satu produk yang dimiliki TBSI adalah Tea Tree Oil. Pada dasarnya produk Tea Tree Oil yang berasal dari tanaman Melaleuca Alternifolia ini sudah digunakan untuk pengobatan dan sudah diidentifikasi sebagai antibiotik oleh New South Wales Chief Chemist pada tahun 1920.

Tea Tree Oil dari The Body Shop ini menjadi produk best-seller dan sangat direkomendasikan dalam situs resmi The Body Shop Indonesia. Selain itu, produk ini juga mendapat penghargaan sebagai "Best of Beauty Skin Care" selama 5 tahun berturut-turut sejak tahun 2014 hingga 2018 di situs femaledaily.com. The Body Shop Tea Tree Oil juga direkomendasikan sebagai Tea Tree Oil terbaik untuk menyembuhkan jerawat, mengobati bekas luka, sebagai aromaterapi, juga sebagai bodycare di beberapa situs lain seperti mybest.com, productnation.co, spiceee.net, beautyjournal by sociolla, dan beautynesia.id.

Jika dibandingkan dengan produk serupa dari beberapa situs ulasan produk kecantikan, The Body Shop Tea Tree Oil memiliki rating yang paling tinggi dengan ulasan terbanyak dan mayoritas memiliki ulasan positif yang merekomendasikan orang lain untuk menggunakan produk tersebut.

Dalam situs ulasan femaledaily.com hingga 26 November 2019, The Body Shop Tea Tree Oil memiliki 3163 ulasan dengan rating 3,6 dari 5 dimana $64 \%$ dari keseluruhan ulasan merekomendasikan produk ini. Produk seharga Rp129.000,00 ini juga memiliki ulasan yang baik di beberapa marketplace di Indonesia seperi Shopee (1900 ulasan), Tokopedia (148 ulasan), dan Lazada (178 ulasan).

Purivera Botanicals Tea Tree Oil merupakan salah satu produk pesaing The Body Shop Tea Tree Oil. Dalam situs ulasan femaledaily.com, hingga 26 November 2019, produk ini hanya memiliki 143 ulasan dan 124 pengguna yang merekomendasikan produk ini. Alasan mereka memilih produk ini karena Purivera Botanicals Tea Tree Oil seharga Rp55.000,00 ini lebih murah jika dibandingkan dengan The Body Shop Tea Tree Oil.

Maka pada penelitian ini akan dilakukan analisis sentimen terhadap produk The Body Shop Tea Tree Oil berdasarkan ulasan penggunanya yang terdapat pada situs ulasan produk kecantikan dengan menggunakan machine learning dan menerapkan metode Nä̈ve Bayes Classifier.

\section{Kajian Teori}

\section{Data}

Menurut Lubis (2016), data adalah fakta-fakta yang menggambarkan suatu kejadian yang sebenarnya pada waktu tertentu. 
Lain pula menurut Anhar (2010), data merupakan kenyataan yang menggambarkan suatu kejadian dan merupakan kesatuan nyata yang nantinya akan digunakan sebagai bahan dasar suatu informasi.

Menurut Paramita (2016) Data merupakan suatu bentuk keteranganketerangan yang belum diolah atau dimanipulasi sehingga belum begitu berarti bagi sebagian pemakai. Supaya menjadi berguna, data perlu diolah terlebih dahulu menjadi sebuah informasi.

Jadi dapat disimpulkan bahwa data ialah data yang disimpan dalam bentuk file dimana data tesebut belum diolah tetapi disimpan untuk memberikan arti tertentu kepada orang yang membutuhkan data tesebut.

Data yang kami gunakan awalnya tidak terstruktur dimana format datanya belum di klasifikasikan dan di olah menjadi data terstuktur, lalu hasil olahan data tersebut dapat di tunjukan dengan tabel.

\section{Text Mining}

Menurut Feldman (2016), text mining merupakan bagian dari data mining dimana proses yang dilakukan utamanya adalah melakukan ekstraksi pengetahuan dan informasi dari pola-pola yang terdapat dalam sekumpulan dokumen teks menggunakan alat analisis tertentu.

Menurut Aditya (2015) definisi, Text Mining adalah proses menambang data yang berupa teks dimana sumber data biasanya didapatkan dari dokumen dan tujuannya adalah mencari katakata yang dapat mewakili isi dari dokumen sehingga dapat dilakukan analisis keterhubungan antar dokumen tersebut Text mining mengekstrak informasi berguna dari sumber data melalui identifikasi dan eksplorasi yang tidak dalam bentuk data.
Menurut Fauziah (2019) Text mining dapat didefiniskan sebagai suatu proses menggali informasi dimana seorang user berinteraksi dengan sekumpulan dokumen menggunakan tool analisis yang merupakan komponen-komponen dalam data mining.

Text mining bertujuan untuk mencari kata-kata yang dapat mewakili apa yang ada didalam dokumen sehingga dapat dilakukan analisa keterhubungan antar dokumen.

Text mining mempermudah data scientist dan data analyst untuk memahami dan mempelajari data yang tidak terstruktur dengan skala yang besar melalui program machine learning seperti Rapidminer dan Orange.

\section{Klasifikasi}

Menurut Oktanisa (2018), klasifikasi merupakan teknik dalam data mining untuk mengelompokkan data berdasarkan keterikatan data terhadap data sampel.

Terdapat beberapa algoritma klasifikasi yang banyak digunakan secara luas, seperti Decision/Classification trees, Bayesian Classifier/Naive Bayes Classifier, Neural Network, Analisa Statistik, Algoritma Genetika, Rough Sets, K-Nearest Neighbor, Rule Based Method, Memory Based Reasoning, dan Support Vector Machine.

Dalam klasifikasi, terdapat target variabel kategori. Sebagai contoh, penggolongan pendapatan dapat dipisahkan dalam tiga kategori, yaitu pendapatan tinggi, pendapatan sedang, dan pendapatan rendah.

Sebelum melakukan klasifikasi, data yang ingin kami gunakan sangat bervariasi untuk berbagai macam produk. Dengan melakukan klasifikasi, kami bisa mendapatkan data sesuai dengan produk yang ingin kami tuju. 


\section{Naïve bayes}

Menurut Saleh (2015), Naive Bayes merupakan sebuah pengklasifikasian probabilistik sederhana yang menghitung sekumpulan probabilitas dengan menjumlahkan frekuensi dan kombinasi nilai dari dataset yang diberikan. Algoritma mengunakan teorema Bayes dan mengasumsikan semua atribut independen atau tidak saling ketergantungan yang diberikan oleh nilai pada variabel kelas. Definisi lain mengatakan Naive Bayes merupakan pengklasifikasian dengan metode probabilitas dan statistik yang dikemukan oleh ilmuwan Inggris Thomas Bayes, yaitu memprediksi peluang di masa depan berdasarkan pengalaman di masa sebelumnya.

Menurut Fadlan (2018), Naïve Bayes merupakan teknik prediksi berbasis probabilitas sederhana yang berdasarkan pada penerapan teorema Bayes dengan asumsi independen yang kuat. Naïve Bayes menggunakan model fitur independen, maksud independen yang kuat pada fitur adalah bahwa data tidak berkaitan dengan data lain dalam kasus yang sama ataupun atribut yang lain.

Menurut Saleh (2015) Naive Bayes didasarkan pada asumsi penyederhanaan bahwa nilai atribut secara kondisional saling bebas jika diberikan nilai output. Dengan kata lain, diberikan nilai output, probabilitas mengamati secara bersama adalah produk dari probabilitas individu.

\section{Analisis Sentimen}

Menurut Nurjanah (2017) Analisis sentimen dilakukan untuk menentukan apakah opini atau komentar terhadap suatu permasalahan, memiliki kecenderungan positif atau negatif dan dapat dijadikan sebagai acuan dalam meningkatkan suatu pelayanan, ataupun meningkatkan kualitas produk.
Menurut Sipayung (2016) Analisis sentimen adalah sebuah cara yang digunakan untuk mengolah komentar yang diberikan oleh pemesan atau pelanggan melalui berbagai media, mengenai sebuah produk, jasa ataupun sebuah instansi.

Menurut Nugroho (2016) tugas dasar analisis sentimen adalah mengelompokkan polaritas dari teks yang ada dalam dokumen, kalimat, atau pendapar. Polaritas mempunyai arti apakah teks yang ada dalam dokumen, kalimat, atau pendapat memiliki aspek positif atau negatif.

Sentiment analysis adalah kegiatan melakukan analisa terhadap pendapat, opini, sikap atau emosi seseorang mengenai suatu produk, topik atau permasalahan tertentu sehingga bisa diketahui hal tersebut masuk kedalam sentimen positif, negatif atau netral.

\section{METODOLOGI PENELITIAN}

Pada kegiatan ini kami menggunakan metode Sentimen Analysis. Output dari analisis ini yaitu sentimen konsumen yang menggunakan produk The Body Shop Tea Tree Oil berdasarkan ulasan konsumen di forum femaledaily.com. Sentimen positif dan negatif ditentukan dari ulasan konsumen berdasarkan pengalaman mereka dalam menggunakan produk Tea Tree Oil.

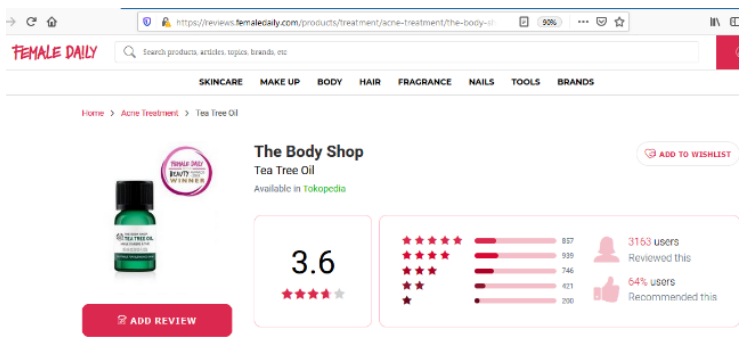

Gambar 1. The Body Shop Tea Tree Oil di femaledaily.com 


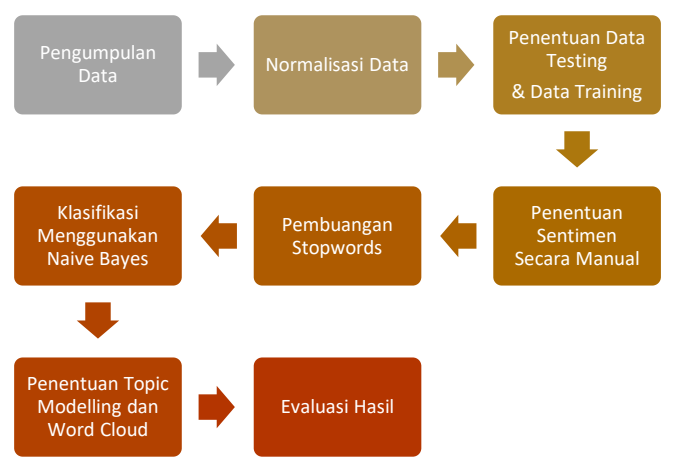

Bagan 1 Metodologi Penelitian

\section{Pengumpulan Data}

Tahap awal merupakan pengumpulan data. Data yang digunakan berasal dari ulasan pengguna produk Tea Tree Oil The Body Shop di situs forum kecantikan femaildaily.com. Data yang didapatkan sebanyak 3062, data tersebut akan dianalisis pada aspek sentimennya.

\section{Normalisasi Data}

Pada tahapan ini dilakukan normalisasi data dengan cara menghilangkan data yang bersifat noise dan inkosisten serta data yang tidak lengkap dan memiliki makna. Jumlah data setelah dilakukan normalisasi data sebanyak 2820 .

\section{Penentuan Data Training dan Data Testing}

Tahapan penentuan data ini dilakukan secara acak, dan membagi data menjadi dua jenis data, yaitu data training dan testing dengan masing-masing jumlah data secara berurutan sebanyak 1974 (70\%) dan $846(30 \%)$. Data training digunakan untuk pembelajaran oleh machine learning dalam memprediksi data testing yang telah ditentukam sebelumnya.

\section{Penentuan Sentimen Secara Manual}

Kegiatan ini dilakukan secara manual dan hanya terhadap data training dengan membagi sentimennya dalam dua kelas, yaitu sentimen positif dan negatif.

\section{Pembuangan Stopwords}

Pada tahap terdapat list kata yang dapat dibuang karena tidak memiliki makna dan pengaruh terhadap proses analisis ini, sehingga kata tersebut sebaiknya dihilangkan karena tingkat kemunculan kata tersebut yang tinggi. Proses pembuangan kata ini dilakukan di dalam machine learning.

\section{Klasifikasi Menggunakan Naïve Bayes} Klasifikasi ini dilakukan di dalam machine learning dengan sifat supervised learning dengan membagi sentimen menjadi positif dan negatif. Pada dasarnya proses klasifikasi Naive Bayes mengggunakan metode probabilistik dan menentukan data yang diinginkan berdasarkan pembelajaran yang sebelumnya dilakukan terhadap data training.

\section{Penentuan Topic Modelling dan Word Cloud}

Kegiatan penentuan ini dilakukan di dalam machine learning. Pada topic modelling machine learning akan menampilkan topik apa yang paling serimg dibahas berdasarkan ulasan pemgguna. Word cloud akan menampilkan kata yang paling sering muncul dengan menyerupai bentuk awan, semakin sering kata tersebut muncul maka akan semakin besar ukurannya, begitupun sebaliknya.

\section{Evaluasi Hasil}

Tahap akhir ini bertujuan untuk mengetahui tingkat akurasi dan presisi yang dari hasil klasifikasi machine learning dan topik pembicaraan yang dilakukan oleh penggunanya serta kata yang sering dikeluarkan oleh pengguna.

\section{HASIL DAN PEMBAHASAN}

Untuk performance vactor positif terdapat 1026 komentar yang dianggap positif dalam ulasan. Machine learning 
menyimpulkan bahwa komentar yang dianggap benar-benar positif sebanyak 770 komentar dan 256 komentar dianggap negatif. Dengan presentase recall sebesar $60.63 \%$ dan presentase precision sebesar $75.05 \%$

Untuk performance vactor negatif, terdapat 938 komentar yang dianggap negatif dalam ulasan. Machine learning menyimpulkan bahwa komentar yang dianggap benar-benar negatif sebantyak 438 komentar dan 500 komentar dianggap positif. Dengan presentase recall sebesar $63.11 \%$ dan presentase precision sebesar $46.70 \%$.

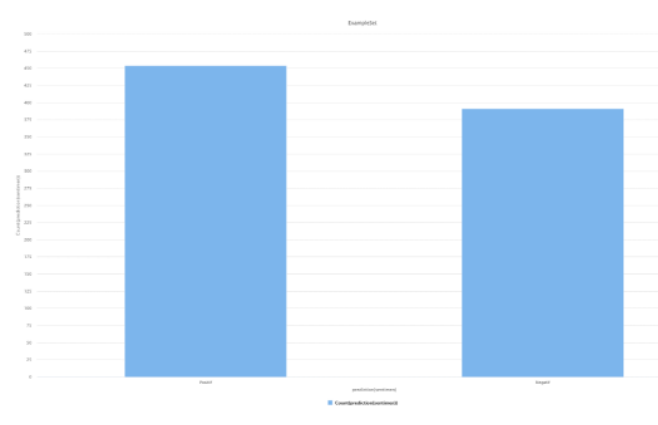

Gambar 2. Grafik Batang Data Testing

Berdasarkan data tersebut, menghasilkan kesimpulan bahwa tingkat akurasi model sentiment analysis Tea Tree Oil pada femaledaily sebesar $61.51 \%$

Dalam grafik tersebut menunjukkan bahwa terdapat 845 komentar yang terbagi menjadi positif dan negatif, dimana jumlah sentiment positif lebih banyak daripada

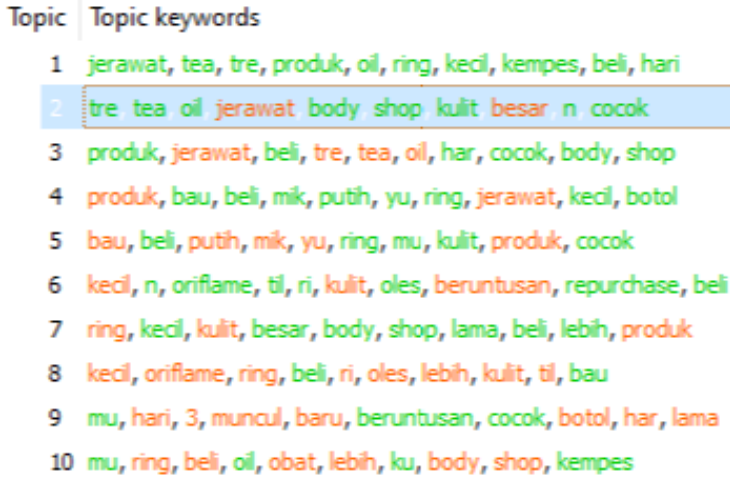

sentiment negatif yaitu sejumlah komentar 454 positif dan 391 komentar negatif.

Gambar 3 Topic Modelling Ulasan Positif

Topic modelling digunakan untuk menunjukkan topik yang sedang dibicarakan oleh pengguna, dalam kasus ini merupakan pengguna femaledaily mengenai produk Tea Tree Oil. Topic modelling dibuat menjadi 10 topik, dalam ulasan positif, terdapat kata kunci topik antara lain jerawat, tea, tre, produk, oil, ring, kecil, kempes, beli dan hari.

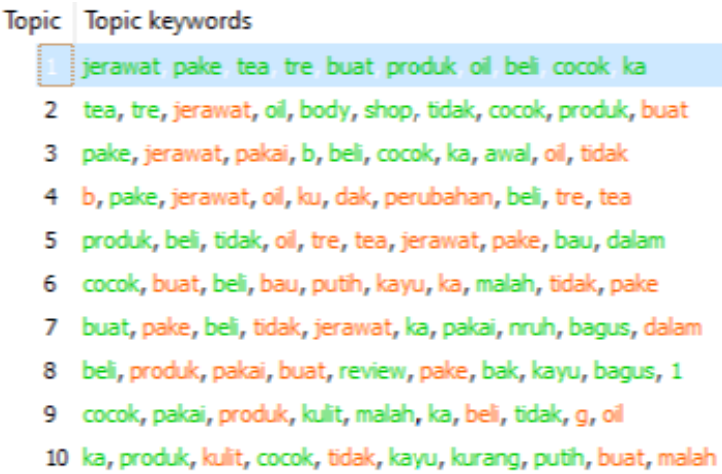

Gambar 4. Topic Modelling Ulasan Negatif

Sedangkan untuk topic modelling dalam ulasan negatif, terdapat kata kunci topik antara lain jerawat, pake, tea, tre, buat, produk, oil, beli, cocok, dan ka.

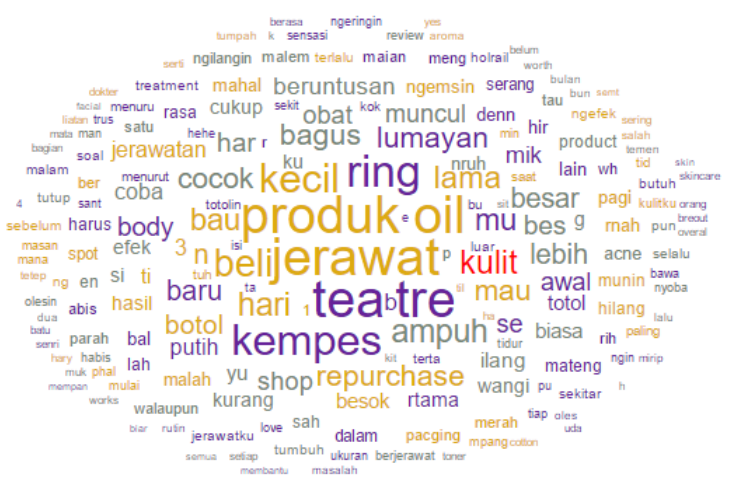

Gambar 5. Word Cloud Ulasan Positif 
Word cloud digunakan untuk menampilkan kata-kata yang sering dibicarakan oleh pengguna, pada kasus ini merupakan pengguna femaledaily terhadap produk Tea Tree Oil. Dalam ulasan positif dengan jumlah komentar sebanyak 1480 komentar, terdapat sebanyak 4375 kata, kata yang paling sering digunakan yaitu kata "jerawat" dengan jumlah 3523 kata, 813 kata untuk "produk", 792 kata untuk "tea", 789 kata untuk "tre" dan 668 kata untuk "oil".

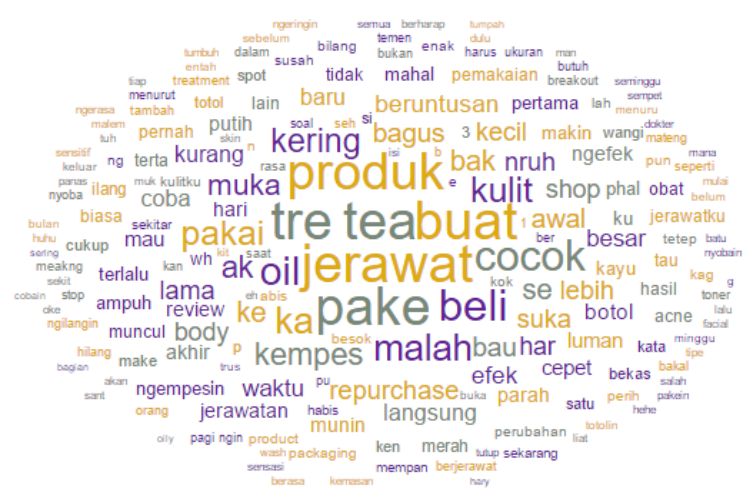

Gambar 6. Word Cloud Ulasan Negatif

Sedangkan untuk ulasan negatif dengan jumlah komentar sebanyak 1329 komentar, terdapat kata sebanyak 3625 kata, kata yang paling sering digunakan yaitu kata "jerawat" dengan jumlah 1724 kata, 756 kata untuk "pake", 476 kata untuk "tea", 472 kata untuk "buat" dan 468 kata untuk "tre".

Berdasarkan data dari metode sentiment analysis, topic modelling dan word cloud terhadap ulasan komentar dari produk Tea Tree Oil, diketahui bahwa jumlah pengguna yang memberikan respon positif terhadap produk tersebut lebih banyak dibandingkan jumlah respon negatifnya. Kata "jerawat" menjadi kata yang paling sering digunakan baik dalam komentar positif maupun komentar negatif.

\section{KESIMPULAN}

Produk Tea Tree Oil yang diproduksi oleh The Body Shop pada situs femaledaily menjadi salah satu produk yang digemari oleh pengguna. Hal tersebut dibuktikan dengan jumlah komentar ulasan yang didominasi oleh komentar positif. Terdapat penggunaan kata seperti kempes, repurchase, ampuh, dan kata lain yang menunjukkan reaksi positif dimana pengguna merasa puas terhadap produk tersebut. Terdapat juga penggunaan kata seperti bau, parah, kering, dan kata lain yang menunjukkan reaksi negatif dimana pengguna tidak puas dengan produk tersebut.

Saran kami untuk perusahaan khususnya The Body Shop yaitu tetap menjaga dan mempertahankan kualitas setiap produknya, serta mempertimbangkan dan memperbaiki halhal yang dikeluhkan oleh pengguna pada komentar ulasan produk, salah satunya yaitu aroma yang kurang disukai. Pengembangan produk terutama pada formula juga perlu dilakukan untuk menangani permasalahan yang dialami pengguna, seperti kulit kering, timbul merah-merah, dan keluhan lainnya. Hal tersebut dapat dijadikan acuan untuk perusahaan agar terus berkembang dan dapat memuaskan pengguna.

\section{REFERENSI}

[1] Aditya, B. (2016). Penggunaan Web Crawler Untuk Menghimpun Tweets dengan Metode PreProcessing Text Mining. Jurnal Infotel, Vol. 7 No. 2.

[2] Annur, H. (2018). Klasifikasi Masyarakat Miskin Menggunakan Metode Naive Bayes. ILKOM Jurnal Ilmiah Volume 10 Nomor 2, 160-165.

Ati, M. Si., D., Prof. Dr. Nurdien, Kistanto, M.A., H., \& Taufik, S.Sos., A. (n.d.). Pengantar Konsep Informasi, Data, dan Pengetahuan. 
[3] Fadlan, C. N. (2018). Penerapan Metode Naive Bayes dalam Klasifikasi Kelayakan Keluarga Penerima Beras Rastia. Jurnal Teknik Informatika Musirawas (JUTIM), Vol 3 No.1, 1-8.

[4] Fauziah, S. (2019). Optimasi Algoritma Vector Space Model dengan Algoritma K-Nearest Neighbor Pada Pencarian Judul Artikel Jurnal. Jurnal PILAR Nusa Mandiri, Vol. 15 No. 1.

[5] Kurniawan, B., Effendi, S., \& Sitompul, O. S. (2012). Klasifikasi Konten Berita Dengan Metode Text Mining . JURNAL DUNIA TEKNOLOGI INFORMASI , 1419.

[6] Lestari, N. P. (n.d.). UJI RECALL AND PRECISION SISTEM TEMU KEMBALI INFORMASI OPAC PERPUSTAKAAN ITS SURABAYA.

[7] Mardi, Y. (2016). Data Mining : Klasifikasi Menggunakan Algoritma C4.5. Jurnal Edik Informatika, V2.i2(213-219).

[8] Nugroho, D. (2016). Analisis Sentimen Pada Jasa Ojek Online Menggunakan Metode Naive Bayes . Posiding Seminar Nasional Sains dan Teknologi.

[9] Nurhuda, F., Sihwi, S. W., \& Doewes, A. (2013). Analisis Sentimen Masyarakat terhadap Calon Presiden Indonesia 2014 berdasarkan Opini dari Twitter Menggunakan Metode Naive Bayes Classifier . JURNAL ITSMART.
[10] Nurjanah, W. (2017). Analisis Sentimen Terhadap Tayangan Televisi Berdasarkan Opini Masyarakat pada Media Sosial Twitter menggunakan Metode KNearest Neighbor dan Pembobotan Jumlah Retweet. Jurnal Pengembangan Teknologi Informasi dan Ilmu Komputer.

[11] Oktanisa, I., \& Supianto, A. A. (2018). PERBANDINGAN TEKNIK KLASIFIKASI DALAM DATA MINING UNTUK BANK DIRECT MARKETING . Jurnal Teknologi Informasi dan Ilmu Komputer (JTIIK), 567-576.

[12] Paramita, A. (2016). Perancangan Data Warehouse Pada Perpustakaan Yayasan Lentera Insan. Jurnal String, Vol. 1 No. 1.

[13] Saleh, A. (2015). Implementasi Metode Klasifikasi Naïve Bayes Dalam Memprediksi Besarnya Penggunaan Listrik Rumah Tangga . Citec Journal.

[14] Sipayung, E. (2016). Perancangan Sistem Analisis Sentimen Komentar Pelanggan Menggunakan Metode Naive Bayes Classifier. Jurnal Sistem Informasi (JSI), Vol. 8 No. 1. 